\title{
Multivariate Characterization of Bean Varieties According to Yield Production, Mineral and Phenolic Contents
}

\author{
Suzana C. Santos, ${ }^{*, a}$ Pedro H. Ferri, ${ }^{a}$ Marcela R. Santos, ${ }^{a}$ Lourival C. Faria, ${ }^{a}$ \\ Itamar P. Oliveira ${ }^{b}$ and Michael D. T. Thung ${ }^{c}$
}

\author{
anstituto de Química, Universidade Federal de Goiás, CP 131,74001-970 Goiânia-GO, Brazil \\ ${ }^{b}$ Faculdade Montes Belos, Av. Hermógenes Coelho, 340, 76100-000 \\ São Luis de Montes Belos-GO, Brazil
}

${ }^{c}$ Embrapa Arroz e Feijão, CP 179, 75375-000 Santo Antônio de Goiás-GO, Brazil

\begin{abstract}
Nutrientes minerais (Fe, $\mathrm{Ca}, \mathrm{Cu}, \mathrm{Mn}, \mathrm{Mg}$ e Zn) e compostos fenólicos (fenóis totais e taninos) de dezesseis variedades de feijões, cultivados sob condições controladas, foram quantificados. Os dados obtidos das determinações químicas e das produtividades dos feijões foram avaliados empregando métodos multivariados: análise de componentes principais, análise de agrupamentos e análise de correlação canônica. Três grupos de cultivares foram reconhecidos e tanto os minerais $\mathrm{Fe}, \mathrm{Zn}, \mathrm{Cu}$ e $\mathrm{Mn}$ quanto os rendimentos dos feijões foram os principais responsáveis por esta discriminação. Variedades promissoras de feijões para programas de biofortificação ou uso direto em alimentos fortificados foram identificadas principalmente no grupo I, no qual os cultivares Aporé (Fe e Mg), Bambuí ( $\mathrm{Zn})$ e Valente ( $\mathrm{Fe}$ e $\mathrm{Cu}$ ) conciliaram boa produtividade e altos níveis de minerais. O uso da análise de correlação canônica possibilitou detectar relações significativas entre produtividade dos feijões, taninos e os metais $\mathrm{Mg}$, Zn e Mn.
\end{abstract}

The contents of mineral nutrients ( $\mathrm{Fe}, \mathrm{Ca}, \mathrm{Cu}, \mathrm{Mn}, \mathrm{Mg}$, and $\mathrm{Zn}$ ) and phenolic compounds (total phenols and tannins) of sixteen bean cultivars grown under controlled conditions have been quantified. Data obtained from chemical determinations and bean yields were evaluated by multivariate methods, principal components, hierarchical cluster and canonical correlation analysis. Three groups of cultivars were recognized and mineral nutrients $\mathrm{Fe}, \mathrm{Zn}, \mathrm{Cu}$, and $\mathrm{Mn}$ as well as bean yields were the most relevant factors for their discrimination. Potential bean varieties for biofortification programs or direct use in fortified food were identified mainly in cluster I, in which a number of cultivars conciliate good yields and high mineral contents, such as Aporé (Fe and $\mathrm{Mg}$ ), Bambuí ( $\mathrm{Zn}$ ), and Valente ( $\mathrm{Fe}$ and $\mathrm{Cu}$ ). The use of canonical correlation analysis allowed for the detection of significant relationships between bean yield, tannins, and $\mathrm{Mg}, \mathrm{Zn}$, and $\mathrm{Mn}$ metals.

Keywords: Phaseolus vulgaris, mineral nutrients, phenolic compounds, multivariate analysis

\section{Introduction}

The common bean (Phaseolus vulgaris L.) is one of the most important sources of proteins, calories, B-complex vitamins, and minerals in Latin America. In Brazil, the bean consumption per capita is about $17 \mathrm{~kg} / \mathrm{year},{ }^{1}$ which makes this legume essential against severe iron deficiency anaemia, a critical public health problem in South and Central America, affecting as many as $25 \%$ of pregnant women and $40 \%$ of children under 5 years old. ${ }^{2}$ In developing countries, beans are the best non-meat source

\footnotetext{
*e-mail: suzana@quimica.ufg.br
}

of iron, providing 23-30\% of daily recommended levels in a single serving. ${ }^{1}$ Common beans also contribute to human nutrition with other important minerals, such as $\mathrm{Zn}, \mathrm{Ca}$, $\mathrm{Mg}, \mathrm{Mn}$ and $\mathrm{Cu}^{3}$

Mineral contents in bean grains can vary largely depending on the varieties, ${ }^{4,5}$ and on environmental factors, such as soil composition. ${ }^{6}$ Taking into account the nutritional value of beans, another important aspect needs to be considered: the presence of anti-nutritional components, such as tannins, phenols, phytic acids, and calcium, which depress Fe bioavailability. $^{7}$

The majority of bean breeding programs developed in Brazil have focused on improving resistance to 
the disease and cooking performance, in addition to increasing crop yields and maturation rate. ${ }^{8}$ However, the nutritive quality of the seeds has recently been considered in relation to varietal selection. ${ }^{1}$ This process is named biofortification, which increases the amounts of bioavailable essential nutrients through soil fertilization or genetic selection..$^{9,10}$

The objective of this study was to quantify the content of some mineral nutrients ( $\mathrm{Fe}, \mathrm{Zn}, \mathrm{Mg}, \mathrm{Mn}, \mathrm{Ca}$ and $\mathrm{Cu}$ ) and compounds with antinutritional value (total phenols and tannins) of sixteen bean cultivars grown in Brazil and their respective yield production. Chemometric tools (principal component and cluster analyses) were applied to detect pattern distributions of bean cultivars and to identify which parameters differentiate the natural groups. In addition, the canonical correlation analysis was used to study the influence of yield seed production and phenol contents on mineral nutrients.

The multivariate methods of analysis can be a useful tool in selecting cultivars which conciliate good nutritional value and high yields for direct use as biofortified food or potential varieties for biofortification breeding programs.

\section{Experimental}

\section{Plant materials}

The experiment was carried out in Embrapa Arroz e Feijão, Goiás State. Bean plants of sixteen cultivars (Pérola, Aporé, Rudá, Valente, Diamante Negro, Xamêgo, Bambuí, Jalo Precoce, BRS Executivo, SIN 15, AFR 245, WAF 69 , WAF 75, A 195, AND 676, and DRK 18) were raised from seeds in plastic pots (diameter $30 \mathrm{~cm}$, height $35 \mathrm{~cm}$ ) with three seedlings per pot and three pots for each variety. The local soil was enriched with a standard solid fertilizer mixture $\mathrm{N}: \mathrm{P}_{2} \mathrm{O}_{5}: \mathrm{K}_{2} \mathrm{O}$, ratio 10:11:5, and plants were watered once a day. The experiment was performed in a greenhouse with natural photoperiod and light intensities. The pods were harvested from 75 to 120 days, when seeds were still fresh. They were subsequently dried at room temperature in the shade for 7 days.

\section{Standards and chemicals}

The standard tannic acid was obtained from Merck (Darmstadt, Germany), Bovine Serum Albumin V (BSA) fraction from Sigma (Chemical Co. St. Louis, MO, USA), and Folin-Ciocalteu reagent from Riolab (RJ, Brazil). Methanol, sodium dodecyl sulphate, $\mathrm{FeCl}_{3}, \mathrm{HNO}_{3}, \mathrm{H}_{2} \mathrm{O}_{2}$, and $\mathrm{Na}_{2} \mathrm{CO}_{3}$ were purchased from Synth (Labsynth, SP, Brazil), all of which had a reagent grade quality.

\section{Extraction of phenols}

Powdered and dried whole bean seeds ( $2 \mathrm{~g})$ were extracted at room temperature with $80 \% \mathrm{v} / \mathrm{v}$ aqueous methanol in an ultrasonic bath. Samples were extracted with $10 \mathrm{~mL}$ of solvent for $1 \mathrm{~h}$. The extract was separated from the solid residue by centrifuging at $4000 \mathrm{rpm}$ for $15 \mathrm{~min}$ and transferred to a $25 \mathrm{~mL}$ volumetric flask. The same procedure was repeated twice with $10 \mathrm{~mL}$ of solvent for $30 \mathrm{~min}$ and with $5 \mathrm{~mL}$ for $30 \mathrm{~min}$. The extracts were combined to a final volume of $25 \mathrm{~mL} .{ }^{11}$ Immediately after the extraction the samples were analyzed for total phenols and tannins.

\section{Phenol analysis}

Total phenols were quantified by the Folin-Ciocalteu method. A mixture of $0.5 \mathrm{~mL}$ of each extract, $0.5 \mathrm{~mL}$ of Folin-Ciocalteu reagent, and $10 \mathrm{~mL}$ of $\mathrm{Na}_{2} \mathrm{CO}_{3} 1 \mathrm{~mol} \mathrm{~L}^{-1}$ was placed in a $25 \mathrm{~mL}$ volumetric flask. Once the solutions had reacted for $1 \mathrm{~h}$, they were measured at $750 \mathrm{~nm}$ via a Beckman DU-70 spectrophotometer. ${ }^{11}$ Tannins were measured by the protein precipitation assay with the use of BSA. ${ }^{12}$ The extract $(2.0 \mathrm{~mL}$ ) was mixed with $2.0 \mathrm{~mL}$ of the BSA solution $\left(1.0 \mathrm{mg} \mathrm{mL}^{-1}\right)$ and was left to stand for $15 \mathrm{~min}$. The precipitate was separated by centrifuging for $15 \mathrm{~min}$ at $4000 \mathrm{rpm}$ and later dissolved in $4.0 \mathrm{~mL}$ of sodium dodecyl sulphate solution. The absorbance was measured at $510 \mathrm{~nm}$ after $15 \mathrm{~min}$ of the addition of the $\mathrm{FeCl}_{3}$ reagent. All samples in the two assays were analyzed in triplicates and standard curves were constructed with tannic acid. The results were expressed in $\mathrm{mg}$ of tannic acid equivalent $\mathrm{g}^{-1}$ dry seed $\left(\mathrm{mg} \mathrm{g}^{-1}\right)$.

\section{Mineral analysis}

Bean seeds were rinsed four times with deionised water, dried in a ventilated oven at $60{ }^{\circ} \mathrm{C}$ for $24 \mathrm{~h}$, and ground in an agate mortar with an agate pestle to pass an 80 mesh sieve. Powdered samples (1.0 g) were hotplate wet-digested in an open-vessel at $110{ }^{\circ} \mathrm{C}$ for $5 \mathrm{~h}$, using nitric acid-hydrogen peroxide $5: 3 \mathrm{v} / \mathrm{v}$. The acid digests were analyzed for $\mathrm{Fe}, \mathrm{Zn}, \mathrm{Ca}, \mathrm{Cu}, \mathrm{Mg}$ and $\mathrm{Mn}$ by flame atomic absorption spectrometry (Instrumentos Científicos CG AA 7000BC, Brazil). In the case of calcium, lanthanum chloride was added to the mineral solution (final concentration $1 \% \mathrm{~m} / \mathrm{v}$ ) to avoid interference from phosphate. Calibration of measurements was performed using commercial standards. All measurements were carried out using standard flame operating conditions, as recommended by the manufacturer. 


\section{Statistical analysis}

Principal component analysis (PCA) and cluster analysis (CA) were applied to examine the interrelationships between experiment yields, mineral nutrients, and phenol contents using the software package SPAD.N version 2.5, CISIA, France..$^{13}$ Nearest neighbour complete linkage technique by Benzécri algorithm was used as an index of similarity. ${ }^{14}$ Hierarchical clustering was performed according to Ward's variance minimizing method. ${ }^{15}$ Relationships between phenol levels, mineral nutrients, and crop yields were obtained via canonical correlation analysis (CCA) using the SAS CANCORR procedure. The magnitude of structure correlation coefficients (canonical loadings) was used to explain canonical variates. The predictive ability was assessed by canonical redundancy analysis with standardized variance coefficients. Prior to the multivariate analysis, the data was preprocessed by means of auto-scaling and mean centering.

Average multiple comparisons were established by univariate analysis of variance (ANOVA) using SAS GLM analyses. All data were checked for homoscedasticity with Hartley's test (Table 1) or Cochran's test (Tables S1 and S2). These tests revealed significant departures from the basic assumption for the variables total phenols, Fe, Zn, $\mathrm{Mn}$ and $\mathrm{Mg}$ (Table 1), which were transformed by rank (TP), reciprocal ( $\mathrm{Fe}, \mathrm{Zn}$ and $\mathrm{Mn}$ ), and reciprocal square root $(\mathrm{Mg})$. Whenever a difference was established, a post-hoc Tukey test was performed. Results are shown as mean values and are joined by the standard deviation of independent measurements in some cases. $P$-values below 0.05 were regarded as significant.

\section{Results and Discussion}

The public health problem of iron deficiency in Brazil has been controlled by two main strategies: the distribution of ferrous sulphate supplements and the fortification of wheat and corn flour with iron and folic acid. ${ }^{16}$ Despite some successful results, these programs require continuous investment and solid governmental support for long periods. In addition, they focus solely on iron deficiency anemia, whereas other metal deficiencies such as $\mathrm{Zn}, \mathrm{Cu}$ and $\mathrm{Ca}$ have not received the same attention. An alternative for the prevention and treatment of these deficiencies is the biofortification of edible foods that are highly consumed by the population, which is the case of beans in Brazil, with essential minerals. ${ }^{1,10}$

In order to evaluate potential bean cultivars for biofortification programs, sixteen bean varieties were chosen and their mineral nutrients and phenol contents were quantified and analysed together with yield grain production via chemometric methods. Results obtained from the cultivation experiment are listed in Table S1 (see supplementary information, SI) and the concentrations of six metals ( $\mathrm{Fe}, \mathrm{Zn}, \mathrm{Ca}, \mathrm{Mg}, \mathrm{Mn}$, and $\mathrm{Cu}$ ) as well as the levels of total phenols and tannins are summarized in Table S2 (SI).

\section{Chemometric analysis}

The results obtained from PCA and cluster analysis via Ward's technique $(16$ samples $\times 14$ variables $=224$ data $)$ have revealed the existence of a high chemical variability throughout the cultivars of data collection. Figure 1 shows the relative position of the sampling bean cultivars in the discriminant space in relation to a diaxial system originated in the PCA. First PC accounts for $38.1 \%$ of total variance and discriminates well above the $99 \%$ confidence level cultivars with high production of pods and seeds from varieties with lower yields. In addition, the second PC accounts for $20.3 \%$ of total variance and showed a gradient of mineral nutrient concentration, in which cultivars rich in metals load on the PC-2.

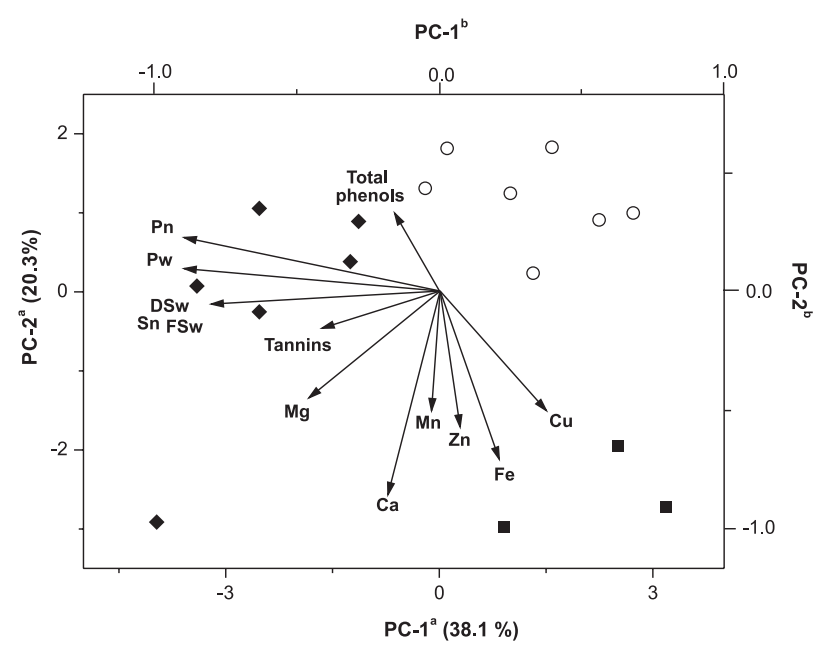

Figure 1. PCA ordination of metal, phenol, yield variables, and bean cultivars to which cluster it belongs: I $(\bullet)$, II $(\boldsymbol{\square})$, and III $(\bigcirc)$. ${ }^{\text {a Axes }}$ refer to ordination scores obtained from cultivar samples. ${ }^{\mathrm{b}}$ Axes refer to ordination scores obtained for the discriminant variables which are represented as vectors from the origin. $\mathrm{TP}=$ Total Phenols, $\mathrm{T}=$ Tannins, $\mathrm{Pn}=$ Pods number, $\mathrm{Pw}=$ Pods weight, $\mathrm{Sn}=$ seeds number, $\mathrm{FSw}=$ Fresh seeds weight, DSw $=$ Dried seeds weight.

Therefore, three types of clusters were found (Figure 2): cluster I comprises only commercial cultivars: Pérola, Rudá, Xamêgo, Valente, Bambuí, and Aporé, it was characterized by high productivity of seeds (number of seeds: $112.83 \pm 12.55, p<0.0001$; weight of dry seeds: $24.51 \pm 3.25 \mathrm{~g}, p<0.0001)$ and high levels of $\mathrm{Mg}(182.7 \pm$ $\left.5.67 \mathrm{mg} 100 \mathrm{~g}^{-1}, p<0.031\right)$. 


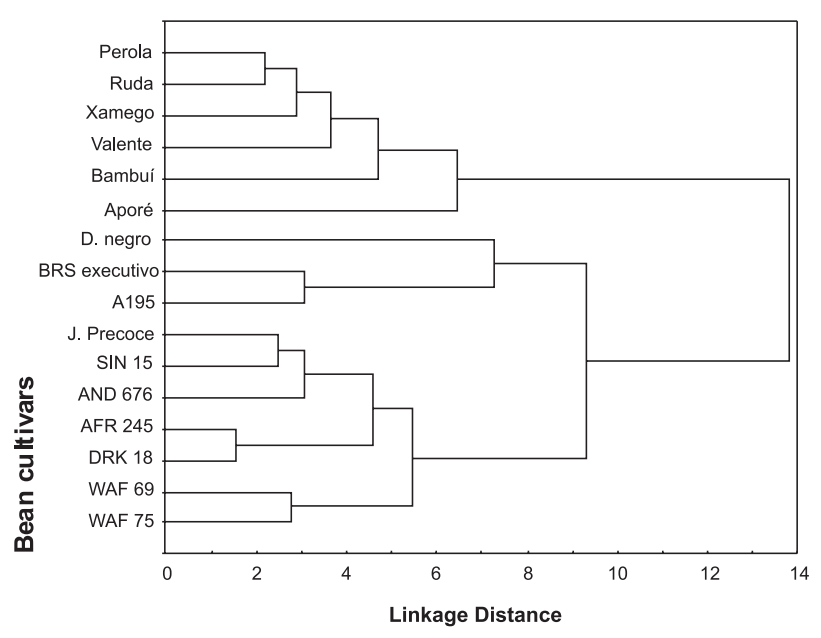

Figure 2. Dendrogram obtained by cluster analysis of bean cultivars using Ward's linkage method.

Cluster II is constituted by three cultivars, Diamante Negro, A 195, and BRS executivo, characterized by the greatest levels of $\mathrm{Fe}\left(12.48 \pm 0.53 \mathrm{mg} 100 \mathrm{~g}^{-1}\right.$, $p<0.011)$, Mn $\left(1.99 \pm 0.09 \mathrm{mg} 100 \mathrm{~g}^{-1}, p<0.14\right)$, $\mathrm{Cu}\left(1.46 \pm 0.05 \mathrm{mg} 100 \mathrm{~g}^{-1}, p<0.014\right), \mathrm{Zn}(3.48 \pm$ $\left.0.10 \mathrm{mg} 100 \mathrm{~g}^{-1}, p<0.019\right)$, and $\mathrm{Ca}(164.30 \pm 0.70 \mathrm{mg}$ $100 \mathrm{~g}^{-1}, p<0.024$ ) (Table 1). Cluster III is composed of seven varieties: DRK 18, AFR 245, AND 676, WAF 69, WAF 75, SIN 15 and Jalo Precoce. They presented the lowest yield of seeds (number of seeds: $45.43 \pm 11.17$, $p<0.008$; weight of dry seeds: $13.70 \pm 2.63 \mathrm{~g}, p<0.022$ ) and a lower concentration of $\mathrm{Mn}\left(1.00 \pm 0.02 \mathrm{mg} 100 \mathrm{~g}^{-1}\right.$, $p<0.031), \operatorname{Mg}\left(138.8 \pm 1.06 \mathrm{mg} 100 \mathrm{~g}^{-1}, p<0.031\right)$,
$\mathrm{Ca}\left(110.00 \pm 3.00 \mathrm{mg} 100 \mathrm{~g}^{-1}, p<0.039\right), \mathrm{Fe}(5.63 \pm 0.11 \mathrm{mg}$ $\left.100 \mathrm{~g}^{-1}, p<0.050\right)$, and tannins $\left(1.37 \pm 0.33 \mathrm{mg} \mathrm{g}^{-1}\right.$, $p<0.045)$ when compared with the other two groups (Table 1).

The Pearson correlation showed two strong positive correlations, $\mathrm{Fe}$ with $\mathrm{Cu}(p<0.01)$ and $\mathrm{Mn}$ with $\mathrm{Zn}$ $(p<0.01)$. The latter was also detected for Andean origin cultivars, ${ }^{3}$ but no relationship was observed between iron and zinc, in contrast to previous studies. . $^{3,410}$

In fact, the canonical correlation analysis (Table 2), which was applied in order to study the influence of the cultivation yield and phenol contents on the amounts of mineral nutrients, revealed that the weight of pods and dried seeds have a direct correlation with magnesium and are related to cultivars from Cluster I. In addition, tannins and the weight of aerial parts from the first set and $\mathrm{Mn}$ and $\mathrm{Zn}$ from the second set load positively onto the first canonical variable, which are related to varieties from Cluster II. The data clearly indicate that the higher the weight of pods and seeds, the lower the levels of manganese and zinc; similar trends were detected for $\mathrm{Zn}$ and $\mathrm{Cu}$ in relation to seed yields. ${ }^{17}$ Furthermore, there was no correlation between tannins and iron, which is in agreement with a previous study. ${ }^{4}$

\section{Relationships between bean cultivar productivity and nutritional value}

The use of chemometric methods of analysis allowed the classification of the cultivars into three natural groups, which are discriminated by yield variables (number and

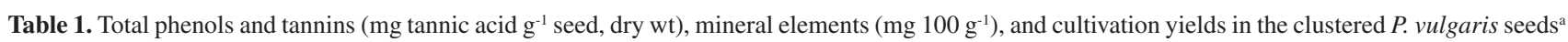

\begin{tabular}{|c|c|c|c|}
\hline \multirow{2}{*}{ Variables } & \multicolumn{3}{|c|}{ Clusters } \\
\hline & I & II & III \\
\hline Total phenols & $2.15 \pm 0.50 \mathrm{a}$ & $1.33 \pm 0.52 \mathrm{a}$ & $2.40 \pm 1.62 \mathrm{a}$ \\
\hline Tannins & $1.72 \pm 0.29 \mathrm{a}$ & $1.59 \pm 0.43 \mathrm{a}$ & $1.46 \pm 0.17 \mathrm{a}$ \\
\hline $\mathrm{Fe}$ & $7.50 \pm 3.50 \mathrm{a}$ & $12.48 \pm 6.45 \mathrm{a}$ & $5.58 \pm 1.10 \mathrm{a}$ \\
\hline $\mathrm{Zn}$ & $2.65 \pm 0.68 \mathrm{a}$ & $3.48 \pm 1.21 \mathrm{a}$ & $2.41 \pm 0.21 \mathrm{a}$ \\
\hline $\mathrm{Ca}$ & $129.33 \pm 37.06 \mathrm{a}$ & $164.33 \pm 8.62 \mathrm{a}$ & $108.14 \pm 31.63 \mathrm{a}$ \\
\hline $\mathrm{Mg}$ & $185.83 \pm 58.93 \mathrm{a}$ & $153.67 \pm 9.24 \mathrm{ab}$ & $133.00 \pm 11.48 \mathrm{~b}$ \\
\hline $\mathrm{Mn}$ & $1.34 \pm 0.29 \mathrm{ab}$ & $1.99 \pm 1.12 \mathrm{a}$ & $1.00 \pm 0.21 \mathrm{~b}$ \\
\hline $\mathrm{Cu}$ & $0.90 \pm 0.39 a$ & $1.45 \pm 0.61 \mathrm{a}$ & $0.81 \pm 0.26 \mathrm{a}$ \\
\hline Dried aerial part (g) & $23.93 \pm 6.22 \mathrm{a}$ & $21.96 \pm 5.28 \mathrm{a}$ & $19.13 \pm 5.04 \mathrm{a}$ \\
\hline Fresh seeds wt (g) & $27.10 \pm 3.88 \mathrm{a}$ & $16.55 \pm 1.68 \mathrm{~b}$ & $17.94 \pm 4.63 \mathrm{~b}$ \\
\hline Dried seeds wt (g) & $24.51 \pm 3.56 \mathrm{a}$ & $11.64 \pm 1.92 \mathrm{~b}$ & $13.70 \pm 2.84 \mathrm{~b}$ \\
\hline Pods wt (g) & $7.22 \pm 0.93 \mathrm{a}$ & $4.69 \pm 0.41 \mathrm{~b}$ & $5.65 \pm 0.62 b$ \\
\hline Pods (n) & $32.50 \pm 2.67 \mathrm{a}$ & $18.00 \pm 4.36 \mathrm{~b}$ & $23.43 \pm 5.77 \mathrm{~b}$ \\
\hline Seeds (n) & $112.83 \pm 13.75 \mathrm{a}$ & $45.00 \pm 24.76 b$ & $45.43 \pm 12.07 \mathrm{~b}$ \\
\hline
\end{tabular}

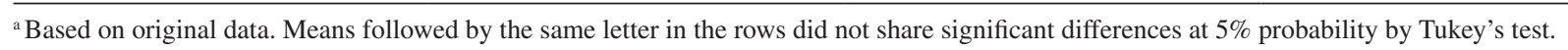


Table 2. Canonical structure (loadings) of phenolic and yield discriminants and mineral nutrients with their canonical variates.

\begin{tabular}{lccc}
\hline $\begin{array}{l}\text { Phenols and } \\
\text { yield (set 1) }\end{array}$ & $\begin{array}{c}\text { Canonical } \\
\text { variate V1 }\end{array}$ & $\begin{array}{c}\text { Minerals } \\
(\text { set 2) }\end{array}$ & $\begin{array}{c}\text { Canonical } \\
\text { variate W1 }\end{array}$ \\
\hline Tannins & 0.6605 & $\mathrm{Zn}$ & 0.2539 \\
Dried aerial parts & 0.6433 & $\mathrm{Mg}$ & -0.3008 \\
Dried seed & -0.2504 & $\mathrm{Mn}$ & 0.6516 \\
Pods (weight) & -0.2889 & & 0.7619 \\
Eingenvalues & & 0.8729 \\
Canonical correlation & & 21.165 \\
$C h i$-square & & 0.1460 \\
Wilks' lambda & & 12 \\
Degrees of freedom & & 0.0480 \\
$P$-value & & 24.9 \\
Cumulative variance $(\%):$ & & 19.3 \\
of discriminant phenols and yield data & & \\
of discriminant phenols and yield-minerals relation & & \\
\hline
\end{tabular}

weight of dry seeds and pods) and mineral variables $\mathrm{Fe}$, $\mathrm{Mn}, \mathrm{Cu}$ and $\mathrm{Zn}$. This classification permits the selection of two potential groups of varieties for use in biofortification breeding programs: the cultivars from Cluster I are characterized by high productivity and by moderate to high levels of metals, whereas the varieties from Cluster II, despite reduced yields, contain the highest amounts of iron and copper (BRS Executivo and A 193) and zinc and manganese (Diamante Negro). Some cultivars from Cluster I conciliate both qualities, good yields and high mineral concentration, such as Aporé ( $\mathrm{Fe}$ and $\mathrm{Mg}$ ), Bambuí $(\mathrm{Zn})$ and Valente $(\mathrm{Fe}$ and $\mathrm{Cu})$.

The challenge of biofortification programs is to produce grains with superior amounts of several essential mineral elements in high yields, even when plants grow in infertile soils. ${ }^{10}$ The increase in concentration of simultaneous metals should be followed by the grain yield or it should at least be unaffected like other qualities. ${ }^{18}$ The relationship between minerals and yield is still uncertain, Fe seems to be yield-independent, whereas $\mathrm{Zn}, \mathrm{Mn}$ (Table 2), Cu, and B are negatively correlated with yield, ${ }^{17}$ and $\mathrm{Mg}$ is positively correlated (Table 2).

High amounts of anti-nutrients such as tannins can decrease the bioavailability of metals and proteins from the seeds, ${ }^{7}$ as these compounds are able to form chelates with $\mathrm{Fe}(\mathrm{III}), \mathrm{Cu}(\mathrm{II})$ and $\mathrm{Zn}(\mathrm{II})$ as well as insoluble complexes with dietary proteins and enzymes. ${ }^{19,20}$ The negative correlation between tannins and yield variables, weight of dry seeds and pods (Table 2), reflects the plant strategy to invest in the primary metabolism for growth and reproduction instead of in secondary compounds for defense. This trend is normally observed when plants grow in fertile soils without herbivore stress. ${ }^{21}$

\section{Conclusions}

Six mineral elements, phenol contents, and yields were used to characterize sixteen bean cultivars by the application of a chemometric approach. Employing multivariate methods of analysis, such as PCA, CA, and CCA, it was possible to highlight correlations between the investigated parameters and to outline some patterns. The statistical evaluation led to the distinction of three groups of cultivars, in which mineral nutrients $\mathrm{Fe}, \mathrm{Zn}, \mathrm{Cu}$, and $\mathrm{Mn}$ and yields were most responsible for their discrimination. These methods are useful for the detection of potential bean cultivars for biofortification programs or for direct use in fortified food and supplements which may prevent or treat mineral deficiencies.

\section{Supplementary Information}

Cultivars with respective cultivation yields, and phenolics and minerals contents are available free of charge at http://jbcs.sbq.org.br as PDF file.

\section{Acknowledgments}

The authors are indebted to CNPq and FUNAPE/UFG for financial support.

\section{References}

1. Broughton, W. J.; Hernandez, G.; Blair, M.; Beebe, S.; Gepts, P.; Vanderleyden, J.; Plant Soil 2003, 252, 55.

2. Llanos, A.; Tereza Oyarzún, M.; Bonvecchio, A. J.; Rivera, A.; Uauy, R.; Public Health Nutr. 2008, 11, 466; Castro, T. G.; Baraldi, L. G.; Muniz, P. T.; Cardoso, M. A.; Public Health Nutr. 2009, 12, 2335.

3. Beebe, S.; Gonzalez, A. V.; Rengifo, J.; Food Nutr. Bull. 2000 , $21,387$.

4. Welch, R. M.; House, W. A.; Beebe, S.; Cheng, Z.; J. Agric. Food Chem. 2000, 48, 3576.

5. Shimelis, E. A.; Rakshit, S. K.; LWT-Food Sci. Technol. 2005, 38, 331.

6. Moraghan, J. T.; Padilla, J.; Etchevers, J. D.; Grafton, K.; Acosta-Gallegos, J. A.; Plant Soil 2002, 246, 175; Sammán, N.; Maldonado, S.; Alfaro, M. E.; Farfán, N.; Gutierrez, J.; J. Agric. Food Chem. 1999, 47, 2685.

7. Viteri, F. E.; In Prevention of Micronutrient Deficiencies. Tools for Policymakers and Public Health Workers; Howson, C. P., Kennedy, E. T., Horwitz, A., eds., National Academy Press: Washington DC, 1999, ch. 3. 
8. Bertoldo, J. G.; Coimbra, J. L. M.; Barili, L. D.; Vale, N. M.; Rocha, F.; Rev. Cienc. Agron. 2009, 40, 135.

9. House, W. A.; Welch, R. M.; Beebe, S.; Cheng, Z.; J. Sci. Food Agric. 2002, 82,1452; Nestel, P.; Bouis, H. E.; Meenakshi, J. V.; Pfeiffer, W.; J. Nutr. 2006, 136, 1064; Hirschi, K. D.; Annu. Rev. Nutr. 2009, 29, 401.

10. White, P. J.; Broadley, M. R.; Trends Plant Sci. 2005, 10, 586.

11. Escarpa, A.; González, M. C.; Anal. Chim. Acta 2001, 427, 119.

12. Hagerman, A. E.; Butler, L. G.; J. Agric. Food Chem. 1978, 26, 809.

13. Lebart, L.; Morineau, A.; Lambert, T.; Pleuvret, P.; Spad Version 5.0. Système Portable d'Analyse de Donnèes Numériques. Centre International de Statistique et d'Informatique Appliquées, Saint Mandé, France, 2000.
14. Benzécri, J. P.; L'Analyse Des Données: la Taxinomie. Tome 1, Dunod: Paris, 1980.

15. Ward, J.H.; J. Am. Stat. Assoc.1963, 58, 238.

16. Coutinho, G. G. P. L.; Goloni-Bertollo, E. M.; Bertelli, E. C. P.; Sao Paulo Med. J. 2005,123, 88.

17. Ribeiro, N. D.; Jost, E.; Cerutti, T.; Maziero, S. M.; Poersch, N. L.; Bragantia 2008, 67, 267.

18. Bouis, H. E.; Proc. Nutr. Soc. 2003, 62, 403.

19. Mila, I.; Scalbert, A.; Expert, D.; Phytochemistry 1996, 42, 1551.

20. Haslam, E.; J. Nat. Prod. 1996, 59, 205.

21. Haukioja, E.; Ossipov, V.; Koricheva, J.; Honkanen, T.; Larsson, S.; Lempa, K.; Chemoecology 1998, 8, 133.

Submitted: May 12, 2010 Published online: June 29, 2010 


\title{
Multivariate Characterization of Bean Varieties According to Yield Production, Mineral and Phenolic Contents
}

\author{
Suzana C. Santos, ${ }^{* a}$ Pedro H. Ferri, ${ }^{a}$ Marcela R. Santos, ${ }^{a}$ Lourival C. Faria,${ }^{a}$ \\ Itamar P. Oliveira ${ }^{b}$ and Michael D. T. Thung ${ }^{c}$ \\ ${ }^{a}$ Instituto de Química, Universidade Federal de Goiás, CP 131,74001-970 Goiânia-GO, Brazil \\ ${ }^{b}$ Faculdade Montes Belos, Av. Hermógenes Coelho, 340, 76100-000 \\ São Luis de Montes Belos-GO, Brazil \\ ${ }^{c}$ Embrapa Arroz e Feijão, CP 179, 75375-000 Santo Antônio de Goiás-GO, Brazil
}

Table S1. $P$. vulgaris cultivars and respective cultivation yields

\begin{tabular}{|c|c|c|c|c|c|c|}
\hline Cultivar & Dried aerial part (g) & Fresh seeds $(\mathrm{g})$ & Dried seeds (g) & Pods (g) & Pods (n) & Seeds (n) \\
\hline Pérola & 29.73 & 27.37 & 24.25 & 7.65 & 32 & 91 \\
\hline Rudá & 25.70 & 28.04 & 24.51 & 7.13 & 37 & 133 \\
\hline Xamêgo & 16.44 & 19.83 & 18.92 & 6.17 & 30 & 108 \\
\hline Valente & 30.11 & 26.70 & 22.78 & 6.13 & 34 & 117 \\
\hline Bambuí & 25.44 & 29.94 & 27.86 & 7.75 & 30 & 111 \\
\hline Aporé & 16.17 & 30.74 & 28.73 & 8.46 & 32 & 117 \\
\hline Diamante Negro & 28.04 & 15.43 & 13.19 & 4.80 & 21 & 73 \\
\hline BRS Executivo & 18.51 & 15.74 & 9.50 & 5.03 & 13 & 26 \\
\hline A 195 & 19.32 & 18.48 & 12.23 & 4.23 & 20 & 36 \\
\hline Jalo Precoce & 18.57 & 12.35 & 10.08 & 4.77 & 16 & 36 \\
\hline SIN 15 & 20.49 & 14.93 & 11.13 & 5.35 & 27 & 58 \\
\hline AND 676 & 28.82 & 12.64 & 11.28 & 5.63 & 22 & 28 \\
\hline AFR 245 & 21.17 & 21.10 & 16.37 & 5.65 & 28 & 55 \\
\hline DRK 18 & 15.08 & 20.11 & 16.67 & 6.85 & 32 & 51 \\
\hline WAF 69 & 14.91 & 24.31 & 16.28 & 5.74 & 18 & 55 \\
\hline WAF 75 & 14.86 & 20.16 & 14.08 & 5.58 & 21 & 35 \\
\hline
\end{tabular}


Table S2. Total phenols (TP) and tannins (mg tannic acid $\mathrm{g}^{-1}$ seed, dry wt.) and mineral elements (mg $\left.100 \mathrm{~g}^{-1}\right)$ in $P$. vulgaris seeds ${ }^{\mathrm{a}}$

\begin{tabular}{|c|c|c|c|c|c|c|c|c|}
\hline Cultivar & $\mathrm{TP}$ & Tannins & $\mathrm{Fe}$ & $\mathrm{Zn}$ & $\mathrm{Ca}$ & $\mathrm{Mg}$ & $\mathrm{Mn}$ & $\mathrm{Cu}$ \\
\hline Pérola & $2.38 \pm 0.11 \mathrm{abcd}$ & $1.85 \pm 0.26 \mathrm{a}$ & $4.63 \pm 0.02 \mathrm{jk}$ & $1.97 \pm 0.01 \mathrm{k}$ & $111 \pm 0.03 \mathrm{~h}$ & $184 \pm 0.56 b$ & $1.23 \pm 0.01 \mathrm{~g}$ & $0.74 \pm 0.01 \mathrm{i}$ \\
\hline Rudá & $2.30 \pm 0.36$ bcde & $2.01 \pm 0.15 \mathrm{a}$ & $5.33 \pm 0.04 \mathrm{hi}$ & $2.31 \pm 0.03 \mathrm{~h}$ & $157 \pm 0.12 \mathrm{~g}$ & $167 \pm 1.28 \mathrm{c}$ & $1.51 \pm 0.02 \mathrm{c}$ & $0.59 \pm 0.01 \mathrm{k}$ \\
\hline Xamêgo & $2.57 \pm 0.68 \mathrm{abcd}$ & $2.02 \pm 0.47 \mathrm{a}$ & $4.65 \pm 0.03 \mathrm{jk}$ & $2.62 \pm 0.03 \mathrm{e}$ & $91 \pm 0.05 \mathrm{j}$ & $158 \pm 0.96 \mathrm{~d}$ & $1.40 \pm 0.01 \mathrm{~d}$ & $0.89 \pm 0.01 \mathrm{f}$ \\
\hline Valente & $1.81 \pm 0.07 \mathrm{cdef}$ & $1.54 \pm 0.14 \mathrm{a}$ & $8.43 \pm 0.09 \mathrm{~d}$ & $2.35 \pm 0.05 \mathrm{~h}$ & $106 \pm 0.11 \mathrm{i}$ & $160 \pm 1.64 \mathrm{~d}$ & $0.97 \pm 0.02 \mathrm{k}$ & $1.52 \pm 0.03 \mathrm{c}$ \\
\hline Bambuí & $1.84 \pm 0.09 \mathrm{cdef}$ & $1.30 \pm 0.47 \mathrm{a}$ & $6.55 \pm 0.04 \mathrm{f}$ & $3.92 \pm 0.04 \mathrm{~b}$ & $121 \pm 0.07 \mathrm{f}$ & $143 \pm 0.79 \mathrm{f}$ & $1.79 \pm 0.02 b$ & $0.50 \pm 0.011$ \\
\hline Aporé & $1.99 \pm 0.22$ bcdef & $1.62 \pm 0.18 \mathrm{a}$ & $14.03 \pm 0.16 b$ & $2.74 \pm 0.03 \mathrm{~d}$ & $190 \pm 0.12 \mathrm{a}$ & $303 \pm 1.84 \mathrm{a}$ & $1.15 \pm 0.01 \mathrm{i}$ & $1.17 \pm 0.01 \mathrm{e}$ \\
\hline Diamante Negro & $0.85 \pm 0.01 \mathrm{def}$ & $1.95 \pm 0.40 \mathrm{a}$ & $5.82 \pm 0.06 \mathrm{~g}$ & $4.88 \pm 0.03 \mathrm{a}$ & $166 \pm 0.05 \mathrm{c}$ & $159 \pm 0.48 \mathrm{~d}$ & $3.28 \pm 0.02 \mathrm{a}$ & $0.78 \pm 0.01 \mathrm{~h}$ \\
\hline BRS Executivo & $1.68 \pm 0.42 \mathrm{cdef}$ & $1.69 \pm 0.80 \mathrm{a}$ & $18.66 \pm 0.14 \mathrm{a}$ & $2.85 \pm 0.04 \mathrm{c}$ & $155 \pm 0.11 \mathrm{~d}$ & $143 \pm 1.08 \mathrm{f}$ & $1.36 \pm 0.02 \mathrm{e}$ & $1.97 \pm 0.03 \mathrm{a}$ \\
\hline A 195 & $1.47 \pm 0.18 \mathrm{def}$ & $1.12 \pm 0.30 \mathrm{a}$ & $13.03 \pm 0.10 \mathrm{c}$ & $2.72 \pm 0.02 \mathrm{~d}$ & $172 \pm 0.05 b$ & $159 \pm 0.72 \mathrm{~d}$ & $1.33 \pm 0.01 \mathrm{f}$ & $1.61 \pm 0.01 \mathrm{~b}$ \\
\hline Jalo Precoce & $2.74 \pm 0.05 \mathrm{abcd}$ & $1.25 \pm 0.12 \mathrm{a}$ & $6.51 \pm 0.10 \mathrm{f}$ & $2.69 \pm 0.04 \mathrm{~d}$ & $104 \pm 0.07 \mathrm{i}$ & $151 \pm 1.06 \mathrm{e}$ & $1.01 \pm 0.01 \mathrm{j}$ & $0.64 \pm 0.01 \mathrm{j}$ \\
\hline SIN 15 & $1.68 \pm 0.24 \mathrm{cdef}$ & $1.37 \pm 0.23 \mathrm{a}$ & $5.67 \pm 0.04 \mathrm{gh}$ & $2.24 \pm 0.03 \mathrm{i}$ & $68 \pm 0.031$ & $127 \pm 0.63 \mathrm{i}$ & $1.20 \pm 0.01 \mathrm{~h}$ & $0.74 \pm 0.01 \mathrm{i}$ \\
\hline AND 676 & $4.31 \pm 0.15 \mathrm{a}$ & $1.47 \pm 0.84 \mathrm{a}$ & $7.52 \pm 0.06 \mathrm{e}$ & $2.57 \pm 0.05$ ef & $94 \pm 0.08 \mathrm{j}$ & $132 \pm 0.16 \mathrm{~h}$ & $1.31 \pm 0.03 \mathrm{f}$ & $1.37 \pm 0.03 \mathrm{~d}$ \\
\hline AFR 245 & $3.91 \pm 0.15 a b$ & $1.72 \pm 0.42 \mathrm{a}$ & $4.62 \pm 0.04 \mathrm{jk}$ & $2.22 \pm 0.04 \mathrm{i}$ & $114 \pm 0.11 \mathrm{~g}$ & $128 \pm 1.17 \mathrm{i}$ & $0.89 \pm 0.011$ & $0.64 \pm 0.01 \mathrm{j}$ \\
\hline DRK 18 & $3.30 \pm 0.22 \mathrm{abc}$ & $1.56 \pm 0.19 \mathrm{a}$ & $4.84 \pm 0.05 \mathrm{j}$ & $2.55 \pm 0.06 \mathrm{f}$ & $129 \pm 0.14 \mathrm{e}$ & $141 \pm 1.50 \mathrm{f}$ & $1.04 \pm 0.02 \mathrm{j}$ & $0.67 \pm 0.07 \mathrm{j}$ \\
\hline WAF 69 & $0.35 \pm 0.09$ ef & $1.26 \pm 0.36 \mathrm{a}$ & $4.40 \pm 0.01 \mathrm{k}$ & $2.44 \pm 0.02 \mathrm{~g}$ & $84 \pm 0.02 \mathrm{k}$ & $137 \pm 0.34 \mathrm{~g}$ & $0.68 \pm 0.01 \mathrm{~m}$ & $0.78 \pm 0.01 \mathrm{~h}$ \\
\hline WAF 75 & $0.20 \pm 0.06 \mathrm{f}$ & $1.56 \pm 0.30 \mathrm{a}$ & $5.23 \pm 0.05 \mathrm{i}$ & $2.15 \pm 0.04 \mathrm{j}$ & $164 \pm 0.14 \mathrm{c}$ & $115 \pm 1.00 \mathrm{j}$ & $0.88 \pm 0.021$ & $0.84 \pm 0.02 \mathrm{~g}$ \\
\hline
\end{tabular}

${ }^{a}$ Based on original data. Means followed by the same letter in the columns did not share significant differences at $5 \%$ probability by Tukey's test. 